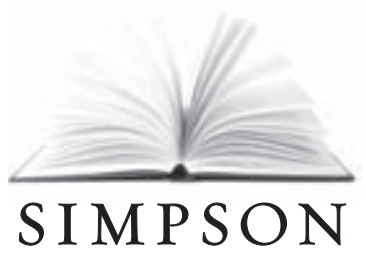

\title{
I MPRINT IN HUMANITIES
}

The humanities endowment

by Sharon Hanley Simpson and

Barclay Simpson honors

MURIEL CARTER HANLEY

whose intellect and sensitivity

have enriched the many lives

that she has touched. 
The publisher gratefully acknowledges the generous contribution to this book provided by the Simpson Humanities Endowment Fund of the University of California Press Associates. 
WILLIAM DEAN

\section{HOWELLS}




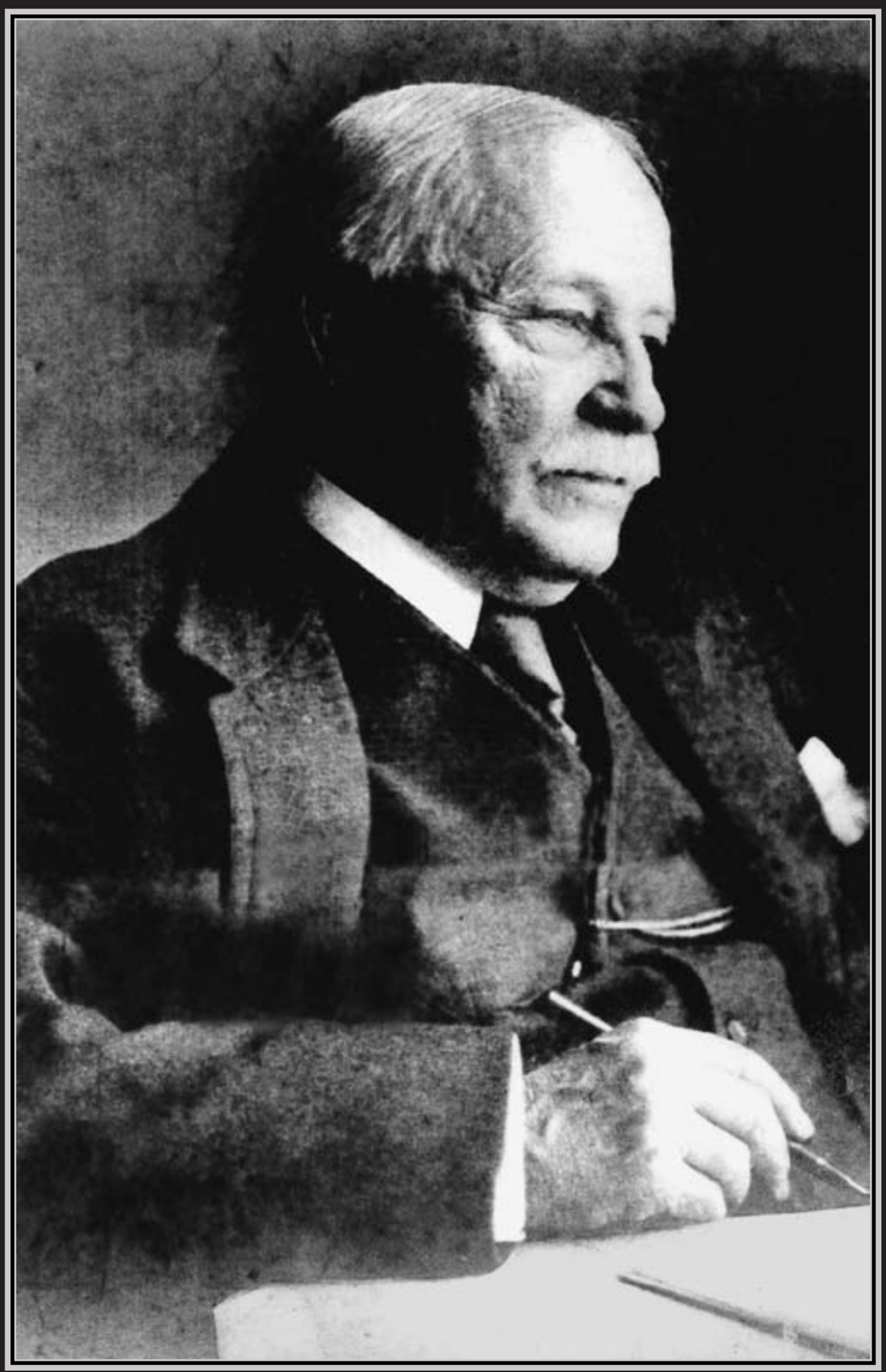




\section{WILLIAM}

DEAN

HOWELIS

\section{A Writer's Life}

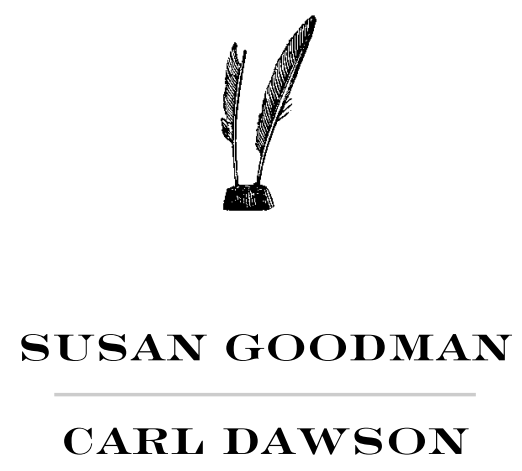

University of California Press . Berkeley Los Angeles London 
University of California Press

Berkeley and Los Angeles, California

University of California Press, Ltd. London, England

(C) 2005 by the Regents of the University of California

Library of Congress Cataloging-in-Publication Data

Goodman, Susan, I95I-.

William Dean Howells : a writer's life /

Susan Goodman and Carl Dawson.

p. $\quad \mathrm{cm}$.

Includes bibliographical references and index.

ISBN 0-520-23896-6 (alk. paper)

I. Howells, William Dean, I837-1920.

2. Novelists, American - 19th century-Biography.

3. Critics-United States - Biography.

I. Dawson, Carl. II. Title.

PS2033.G66 2005

$813^{\prime} \cdot 4-\mathrm{dc22} \quad 2004026562$

Manufactured in Canada

$\begin{array}{llllllllll}\text { I4 } & \text { I3 } & \text { I2 } & \text { II } & \text { IO } & 09 & 08 & 07 & 06 & 05\end{array}$

$\begin{array}{llllllllll}\text { IO } & 9 & 8 & 7 & 6 & 5 & 4 & 3 & 2 & \text { I }\end{array}$

The paper used in this publication meets the minimum requirements of ANSI/NISO Z39.48-1992 (R I997)

(Permanence of Paper). 
For Lawrence D. Stewart 
This page intentionally left blank 
A man remains in a measure strange to himself as long as he lives, and the very sources of novelty in his work will be within himself; he can continue to give it freshness in no other way than by knowing himself better and better.

-w. D. HOWELLs, Literature and Life, 1902 
This page intentionally left blank 